\title{
Фундаментальная наука - источник новых технологий
}

О. А. Лаврентьева, В. В. Родченкова, к. Ф.-м. н.

УДК 543.07

\begin{abstract}
Почти 20 лет назад в Институте физической химии и электрохимии им. А. Н. Фрумкина (ИФХЭ) РАН был создан Центр коллективного пользования физическими методами исследования (ЦКП ФМИ) для решения практических задач по исследованию физикохимических свойств вещества. За прошедшие годы собран высокотехнологичный парк уникального оборудования, который позволяет проводить разнообразные фундаментальные и прикладные исследования с помощью методов рентгено-спектрального анализа, ЯМР, хромато-масс-спектрометрии, рамановской и ИК-спектроскопии, флуоресценции, термоанализа и др. В работе ЦКП ФМИ используется аналитическое оборудование научных лабораторий ИФХЭ РАН. О целях, задачах, достигнутых успехах и особенностях своей работы рассказывают руководители и сотрудники подразделений ЦКП
\end{abstract}

\section{Рассказывает научный руководитепь ЦКП, академик РАН Аслан Юсупович Цивадзе}

Центр коллективного пользования физическими методами исследования организован в 2002 году. Это одна из первых структур в институте, которая создана после назначения меня на должность директора. Тогда ситуация была сложная - в институте не было ни одного импортного прибора. Пришлось поехать в Австрию для переговоров с фирмойпроизводителем, а затем изыскать средства для покупки рентгеновского малоуглового дифрактометра SAXSess (Anton Paar, Австрия). Позже приобретены: монокристальный дифрактометр Карра Apex II (Bruker, Германия), он установлен в радиохимическом корпусе, а затем и новый порошковый дифрактометр Empyrean (Panalytical, Нидерланды). Год назад мы стали обладателями рентгенофлуоресцентного аналитического микроскопа XGT-7200 (Horiba, Япония). И если порошковый и монокристальный дифрактометры часто можно встретить в аналитических лабораториях, то малоугловой дифрактометр и рентгенофлуоресцентный микроскоп редкие и ценные для исследователей приборы.

Оснащение ЦКП спектроскопическим оборудованием мы начали в 2007 году. Первым был один из самых лучших ЯМР-спектрометров высокого разрешения с приставкой для твердых образцов Bruker ADVANCE III 600. Таких приборов в России немного. Потом мы получили рамановский микроспектрометр Senterra (Bruker, Германия). Затем

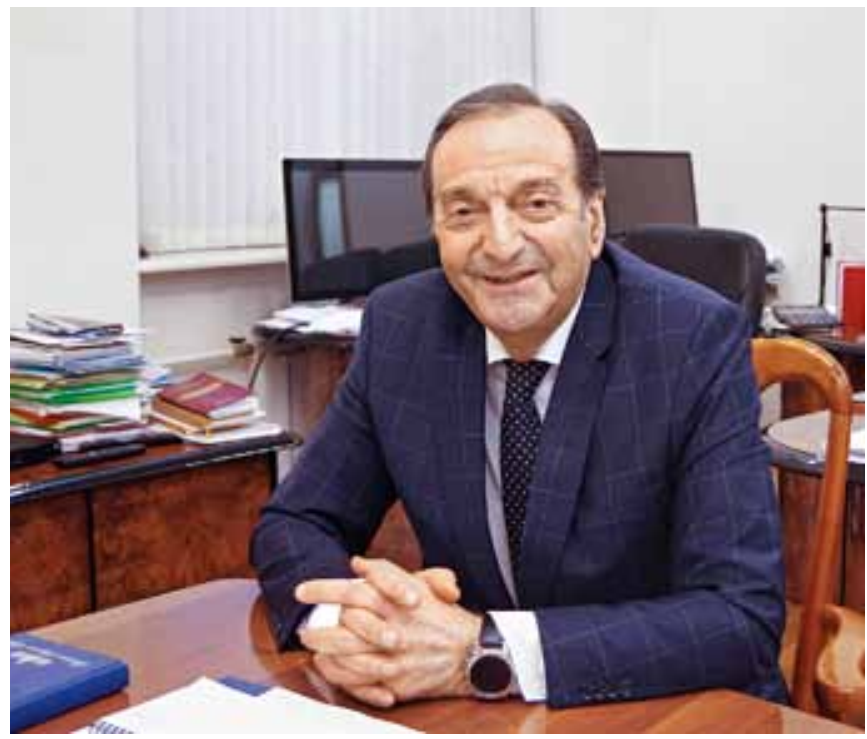

Аслан Юсупович Цивадзе

удалось приобрести также достаточно редкий MALDI-TOF-спектрометр (Bruker) для работы с большими молекулами. Кроме того, в нашем центре есть масс-спектрометр с индуктивно связанной плазмой Agilent 7500c (США).

Некоторое время назад мы заключили договор с "Норильским никелем" и организовали у нас совместную лабораторию. Было закуплено оборудование для производства мембранно-электродных блоков твердооксидных топливных элементов. Договор 
был расторгнут не по нашей вине, однако оборудование осталось в институте.

В результате сложился современный и разнообразный приборный парк ЦКП.

Мой заместитель - ведущий научный сотрудник ИФХЭ РАН, д.х.н. Андрей Альбертович Ширяев фактически руководит и координирует деятельность центра. Так как ЦКП не является структурным подразделением, приборы рассредоточены по разным лабораториям института. Пользоваться оборудованием могут не только наши сотрудники, но и специалисты других учреждений. Создана мощная структура с хорошими перспективами развития и расширения, составляющая достойную конкуренцию аналогичным центрам. Мы ожидаем поступления новых приборов и обновляем устаревшие модели.

В задачи ЦКП входят: экспериментальное и методическое обеспечение проведения на современном уровне фундаментальных и прикладных исследований, в том числе оказание услуг (измерений, исследований и испытаний) заинтересованным пользователям; совершенствование методической базы и разработка новых аналитических методик; обеспечение единства и достоверности измерений при проведении научных исследований; участие в подготовке специалистов и кадров высшей квалификации (студентов, аспирантов, докторантов) на базе современного научного оборудования ЦКП ФМИ; реализация мероприятий программы развития ЦКП ФМИ, в частности, разработка перспективных планов приобретения и внедрения нового научного оборудования, измерительной техники и приборов.

Когда я пришел на работу в институт, среди сотрудников практически не было молодежи. Сегодня у нас нет такой проблемы - около 50\% молодых людей. Мы бережно относимся к нашим сотрудникам. Воспитание кадров - очень трудоемкий процесс, но он того стоит. Зарплата сотрудников в нашем институте зависит от эффективности научного труда. Оплачиваются статьи в высокорейтинговых научных журналах, есть система грантов, коммерческие контракты, патенты и др.

Расскажу о наших успехах, их немало. Можно выделить несколько выдающихся работ последних лет. Удалось разработать безопасные газовые аккумуляторы для автомобилей, это громадное достижение. В отличие от стандартной технологии на основе газовых баллонов, применяется принципиально иной подход: газ аккумулируется в сорбентах совершенно нового поколения. Они эффективно сорбируют газ (например, метан) и прекрасно работают как его источники при определенных условиях. Пробный экземпляр гибридного автомобиля с бензиновым двигателем и газовым аккумулятором создан и уже работает. Конечно, до внедрения пока далеко.

Но самое ценное в том, что мы разработали сорбент, который позволит создавать наземные газовые хранилища. Сегодня хранение и транспортировка газа требует особых условий. С помощью нового сорбента газ можно будет перевозить и на автомобилях, и на кораблях.

Перспективы грандиозные, но внедрение по ряду причин пока задерживается.

Также мы принимаем участие в решении экологических проблем. Например, создаем инженерные барьеры для изоляции выведенных из эксплуатации атомных реакторов. Эти разработки активно используются на Сибирском химическом комбинате (г. Северск).

Предложена уникальная технология разделения редких элементов и в настоящий момент создается демонстрационная установка для извлечения редких металлов из отходов. На конечной стадии получается продукт, содержащий 99,99\% целевого элемента. Именно такие чистые продукты нужны высокотехнологичному производству.

Мы активно развиваем международное сотрудничество - например, давно и успешно работаем с Францией в области радиационной химии. Достижения в этой сфере были оценены по достоинству: в 2016 году я был награжден орденом офицера Академических Пальм.

Затрону еще один важный вопрос. Сейчас очень актуальна тема импортозамещения. Однако сегодняшняя ситуация мне не очень нравится.

В СССР было целое направление в Академии наук вплоть до 90-х годов 20 века - Аналитическое приборостроение. В Ленинграде работал оптический институт, выпускающий хорошую аппаратуру. После войны в ГДР начали производить оптические приборы, но отечественные спектрометры были в то время лучше, чем зарубежные. Дальше ситуация ухудшалась и отрасль постепенно пришла в упадок. Сегодня много хороших разработок, остался даже институт научного приборостроения, но нет производственной базы.

Некоторые наши технологии, например, производства редкоземельных металлов, оказались у китайцев.

У нашей страны высокий научно-технический потенциал, поэтому надо разрабатывать такие приборы, которых нет в мире. Проблема в том, что отсутствует производственная база. Научные разработки стоят дорого, но чтобы наладить серийный выпуск продукции, нужны совсем другие деньги. Надо цех 
построить, обеспечить компьютерное управление, подвести электроснабжение, воду и т.д. Да и проектных институтов уже нет, зато есть проблемы с реактивами, поэтому надо развивать малотоннажную Химию и т.д.
Что касается перспектив, то сейчас мы включаемся в национальные проекты, вскоре будет объявлена программа развития Академии наук. Будем бороться за то, чтобы наш институт получил грант по программе развития приборной базы.

\section{Лаборатория новых химико-физических проблем}

\section{Группа рентгеновских методов анализа}

\section{Рассказывает заместитель научного руководителя ЦКП, ведущий научный сотрудник, доктор химических наук Андрей Альбертович Ширяев}

Сотрудники лаборатории занимаются научными исследованиями с помощью рентгеновских методов анализа. Метод порошковой дифракции достаточно старый, он разработан в 20-х годах прошлого века и имеет две основные сферы применения. Первая - рентгенофазовый качественный и количественный анализ. Широкое применение рентгенофазового анализа объясняется хорошо разработанной теорией, простотой приготовления образцов, относительной экспрессностью получения качественных результатов и сохранением проб без изменения после исследования. Суть метода состоит в идентификации различных кристаллических фаз и определении их относительных концентраций в смесях на основе анализа дифракционной картины, регистрируемой от исследуемых порошковых образцов. Классическая задача из области научной прикладной геологии - определение фазового состава образца керна из нефтеносного пласта, который может состоять из 20-30 минералов: кварца, карбонатов, силикатов и т.д. Очень активно развивается область, связанная со строительными материалами, например, цементом.

Второе большое направление - рентгеноструктурный анализ, то есть расшифровка структуры исследуемого материала, определение параметров решетки, симметрии, расположения атомов и др. Из порошковой дифрактограммы эту информацию получить довольно-таки сложно, первые структуры решены совсем недавно, в конце 90-х годов прошлого века. Один из наших сотрудников, Владимир Васильевич Чернышов, входит в число мировых лидеров по расшифровке сложных структур по результатам порошковой рентгеновской дифракции.

В распоряжении нашей группы есть порошковый рентгеновский дифрактометр высокого класса, но он не единственный в ЦКП. Еще один

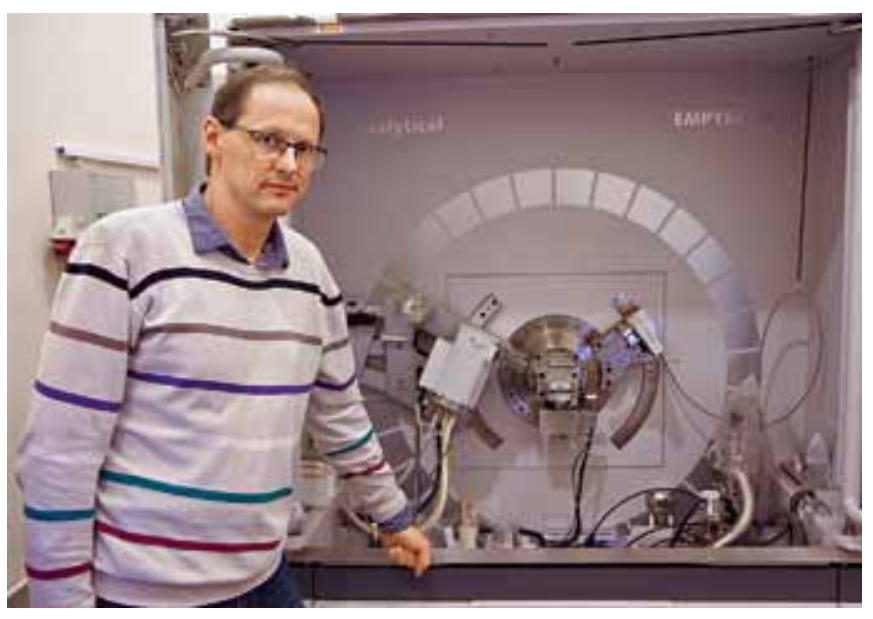

Андрей Альбертович Ширяев

Порошковый дифрактометр Empyrean (Panalytical)

прибор находится в радиохимическом корпусе, что позволяет работать с радиоактивными образцами. Замечу, что в радиохимическом корпусе института также установлен монокристальный дифрактометр Kappa Apex II (Bruker), который активно используют радиохимики, синтезирующие органические и неорганические вещества с радиоактивными элементами - ураном, плутонием, нептунием и пр. Этот редкий прибор позволяет расшифровать кристаллическую структуру неизвестных веществ.

Порошковый дифрактометр Empyrean (Panalytical) имеет очень хорошую конфигурацию с набором различных рентгенооптических элементов. Возможно проведение in situ экспериментов при температурах до $1200^{\circ} \mathrm{C}$ в различных газах или в вакууме.

Дифрактометр позволяет работать не только с порошками, но и с тонкими пленками, исследовать именно планарные структуры, например многослойные органические образцы - порфирины, органические кислоты и др. Однако намного сложнее расшифровать структуру тонкой пленки, чем порошка. 
Отмечу еще раз модульность и простоту работы с прибором: легко заменить одну приставку или оптический элемент на другой.

Приведу классический пример влияния структуры на свойства вещества: графит и алмаз. Это один и тот же углерод, только упакованный по-разному. Белый налет на шоколаде - это то же самое какао-масло, только в другой полиморфной модификации, его нагрели и охладили в неправильных условиях.

В нашей лаборатории есть еще один интересный прибор - рентгеновский малоугловой ди $\Phi^{-}$ рактометр с температурной приставкой и возможностью исследований в геометрии скользящего падения (GISAXS) SAXSess (Anton Paar). Исследуя зависимости интенсивности рассеянного излучения от угла рассеяния можно определить такие характеристики наноразмерных элементов, как их форма и размер, фазовый состав, внутренняя структура, ориентация и распределение. По скорости измерения сравнимы с синхротроном.

Метод малоуглового рентгеновского рассеяния появился перед второй мировой войной, когда начали исследовать распад твердых растворов, например, дюралюминия. Алюминий - металл очень мягкий. Однако его твердые растворы с медью, магнием и рядом других элементов могут распадаться с образованием наноразмерных включений, которые резко повышают механические свойства материала уже с другим названием - дюралюминий. В конце 30-х годов 20 века для исследования наноразмерных неоднородностей был предложен метод малоуглового рассеяния, который позволяет исследовать размер

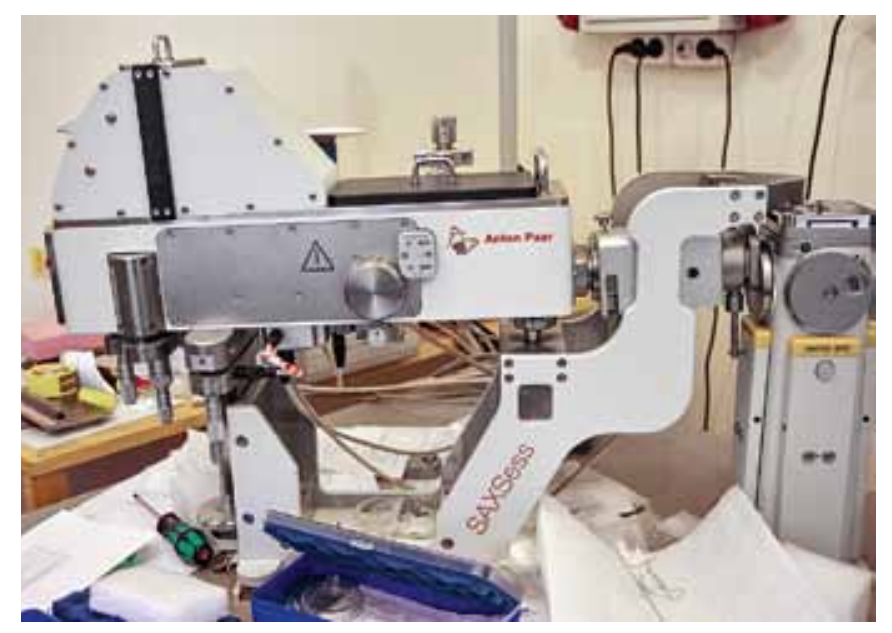

Рентгеновский малоугловой дифрактометр (GISAXS) SAXSess (Anton Paar) и форму наночастиц. Метод сравнительно экзотический, но имеет много применений. С его помощью можно изучать эмульсии, взаимодействия между молекулами и др.

Сегодня малоугловое рассеяние активно используется для исследования белков. Особенно важно, что с помощью дифрактограммы определяют форму объекта, который плавает в растворе. Можно исследовать пористую структуру углеродных адсорбентов. Есть специальная приставка для изучения плоских объектов, например, пленок или образцов после ионной имплантации.

Расскажу еще об одном интересном приборе это рентгенофлуоресцентный аналитический микроскоп XGT-7200 (Horiba scientific, Япония), который представляет собой новое поколение аналитического оборудования. Возможности микроскопа достаточно широкие: спектр определяемых элементов от $\mathrm{Na}$ до U, диаметр пятна меняется от 10 мкм до 1,2 мм, система двойного вакуумирования предоставляет исследователю выбор между режимом полного и частичного вакуума для работы с водосодержащими объектами или биологическими тканями. Одновременно с флуоресценцией при анализе внутренней структуры образца можно получать изображения в проходящих рентгеновских лучах. Программное обеспечение SmartMap записывает полные спектры для каждой точки с одновременным качественным и количественным анализом. Прибор применяется как для научной работы, так и для тестирования новых синтезированных материалов или биологических и природных объектов.

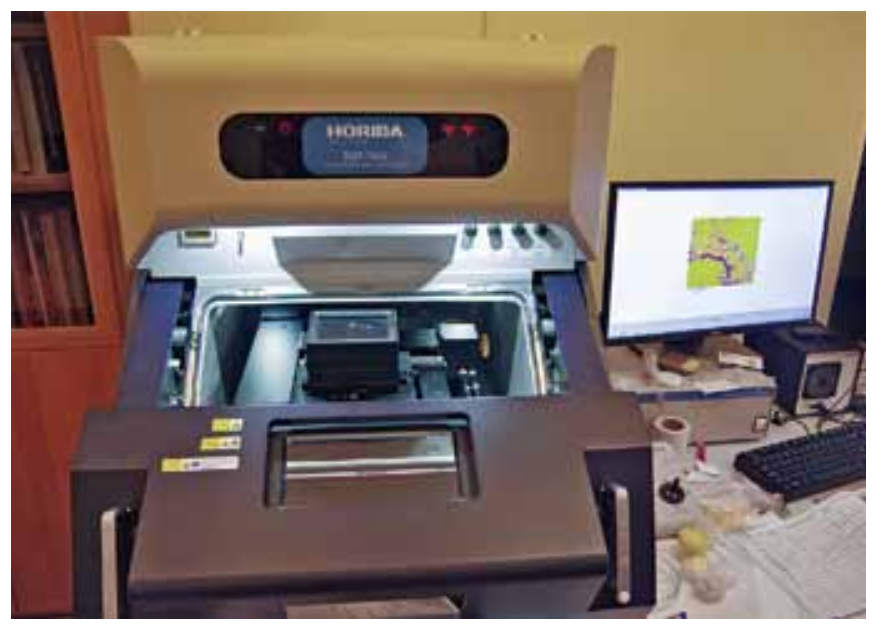

Рентгенофлуоресцентный аналитический микроскоп XGT-7200 (Horiba scientific, Япония) 


\section{Группа спектроскопии}

\section{Рассказывает научный сотрудник Алексей Александрович Аверин}

В нашей лаборатории два основных прибора, первый - спектрометр Senterra (Bruker), который объединяет в себе лазерный рамановский спектрометр для анализа и регистрации спектрального состава излучения и микроскоп для наблюдения микрообъектов. Проба устанавливается на предметный столик между источником лазерного излучения и детектором. При падении лазерного пучка на образец происходит неупругое (комбинационное) рассеяние света на молекулах вещества. В спектре рассеянного излучения появляются линии, характерные для исследуемого соединения, что позволяет идентифицировать вещество и получить информацию о его структуре. Принципиально важной является возможность изучения пространственного распределения различных фаз в неоднородных материалах с разрешением, достигающим единиц микрон. С поступлением нового прибора - inVia Reflex (Renishaw) в нашем распоряжении имеется четыре лазера с различными длинами волн, что позволяет подобрать оптимальные условия исследования конкретного вещества.

Рамановская спектроскопия вместе с инфракрасной спектроскопией поглощения - два дополняющих друг друга метода исследования колебательных спектров молекул вещества. Круг вопросов, которые можно решить с их помощью, достаточно большой. Например, с разрешением в один микрон определить фазы разных частей образца.

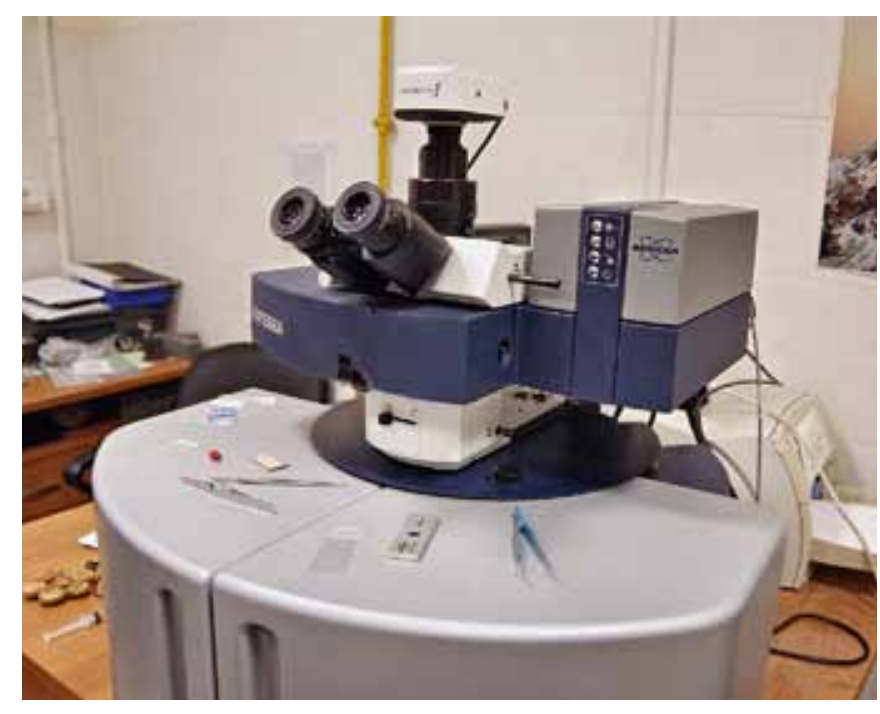

Приведу традиционный пример - графит и алмаз, которые имеют одинаковый химический состав. А поскольку структура разная, то и спектры будут очень сильно отличаться.

Вторая задача - установление структуры органических веществ. По набору характеристических частот в спектре неизвестного образца выделяют серии линий, которые соответствуют определенным молекулярным группам. И таким образом определяют структуру вещества.

Большое достоинство прибора в том, что от очень маленьких объектов можно получить хороший сигнал. Причем для исследований подходят жидкие, твердые образцы и потенциально - газы в запаянном капилляре.

Второй прибор - спектрофлуориметр Fluorolog 3-22 (Horiba, Япония) представляет собой модульную систему с широким ассортиментом дополнительных приспособлений для анализа флуоресценции и ее кинетических характеристик. Высокая чувствительность характеризуется соотношением сигнал/шум от 20000 :1; анализ спектров флуоресценции возможен в широком спектральном диапазоне от 200 нм до 5 мкм. Комплектация позволяет определять квантовый выход, анализировать время жизни возбужденного состояния и анизотропию флуоресценции.

Кюветное отделение с кварцевым окошком достаточно просторное, в него можно устанавливать сосуд Дьюара с жидким азотом для получения спектров при низкой температуре.

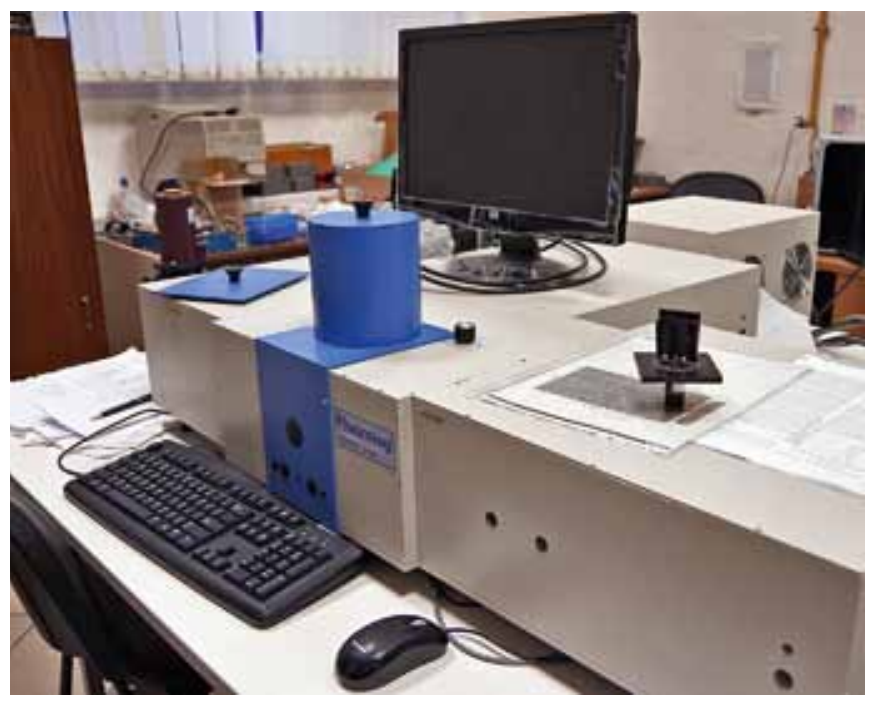

Спектрофлуориметр Fluorolog 3-22 (Ноriba, Япония) 


\section{Группа ЯМР}

\section{Рассказывает старший научный сотрудник, кандидат физико-математических наук Дмитрий Александрович Чешков}

Группа специализируется на применении спектроскопии ядерного магнитного резонанса для изучения структуры органических соединений, межмолекулярных взаимодействий, процессов молекулярной диффузии и др. Объектами исследования являются растворы органических и комплексных соединений в дейтерированных растворителях, поскольку принцип действия метода основан на регистрации сигналов неспаренных ядерных спинов. Мы можем исследовать все магнитно-активные ядра, которые дают сигналы при индукции магнитного поля порядка 14 Тл в диапазоне резонансных частот до 25 до 60 МГц, однако большинство работ основано на исследовании соединений с изотопами ${ }^{13} \mathrm{C}$ и/ или протонами.

Сегодня все публикации, посвященные синтезу новых органических веществ, изучению их свойств или структуры, должны содержать характеристики их спектров ЯМР. Эти данные наряду с массспектрометрическими дополняют друг друга.

Цели исследований и объекты самые разнообразные. Это фотосенсибилизаторы, суперконденсаторы, новые композитные и нанокомпозитные материалы. На определенном этапе их получения необходим органический синтез, результаты которого контролируются с помощью ЯМР-спектроскопии. Интерпретировать спектр не просто, особенно если он принадлежит неизвестному соединению, хотя некоторое понимание о составе вещества, функциональных группах, структурных фрагментах получить можно. Поэтому для достоверного определения структуры органического соединения желательно использовать комплекс методов.

В нашем распоряжении яМР-спектрометр высокого разрешения ADVANCE III 600 (Bruker, Германия). Комплектация и состояние прибора позволяют выполнять все имеющиеся на сегодняшний момент эксперименты ЯМР для жидкостей, например описанные в книге С. Бергера "Больше 200 экспериментов с ЯMP: практический курс" (Stefan Berger. 200 and More NMR Experiments: A Practical Course).

В основном, мы занимаемся прикладными исследованиями, но при этом и сам метод получает свое развитие. Используя готовые аппаратные решения, разрабатываем подходы по теоретическому моделированию эксперимента, обработке и анализу спектров высокого разрешения. Наша научная группа подготовила компьютерную программу по анализу

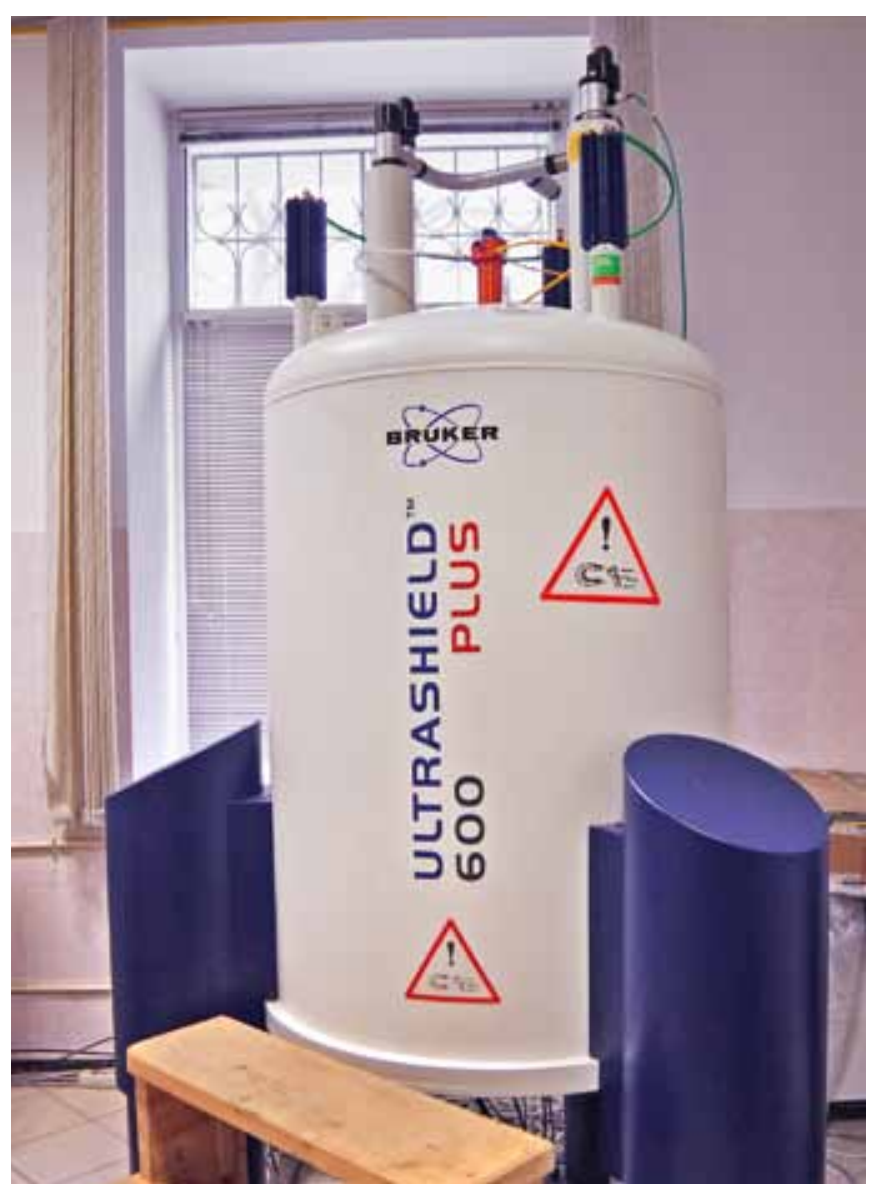

Спектрометр ЯMP Bruker EVANCE III 600

спектров ЯМР, которая сейчас используется во многих ЯМР-центрах в России и за рубежом. Она позволяет успешно расшифровывать спектры, записанные на приборах с малыми полями, а сейчас востребованы настольные ЯМР-спектрометры, у которых рабочие частоты небольшие - порядка 80 МГц. При интерпретации зарегистрированных на таких приборах спектров возникают определенные особенности и трудности в их расшифровке. Наш программный комплекс позволяет успешно такие спектры анализировать.

Мы занимаемся вопросами определения параметров спиновой системы и резонансных частот из экспериментальных спектров ЯМР. Оказывается, в некоторых случаях одному спектру может соответствовать несколько параметров и возникают неоднозначности, то есть обратная задача корректного решения не имеет. Мы предлагаем способы, как снимать и преодолевать такие сложности. Каждый спектр расшифровывается отдельно, но при этом параметры, в общем, должны укладываться в литературные диапазоны.

Программа доступна всем желающим и опубликована на репозитории GitHub. 


\section{Лаборатория биоэлектрохимии}

\section{Рассказывает заместитель директора института по научной работе, заведующий пабораторией биоэлектро- химии, кандидат физико-математических наук Олег Вячеславович Батищев}

В нашей лаборатории занимаются исследованиями биологических объектов с помощью атомной силовой микроскопии. На уровне отдельных молекул мы пытаемся понять механизмы взаимодействия различных компонентов живых клеток, процессы самоорганизации белков и липидов. Изучаем, как они регулируются в природе и как можно воздействовать на эти процессы с точки зрения борьбы с различными патологиями.

Принцип работы атомного силового микроскопа можно представить по аналогии с воспроизведением музыки на граммофоне. Неподвижная игла касается равномерно перемещающейся пластинки с бороздками, в результате возникает звуковая волна. Здесь, в принципе, то же самое, только игла движется вдоль поверхности, отмечая шероховатости за счет системы обратной связи. Луч лазера отражается от кантилевера (это гибкий зонд), и по смещению этого луча видно, когда зонд начинает изгибаться, реагируя на рельеф поверхности. Эти исследования можно вести на воздухе, в вакууме, в жидких средах. Метод универсальный, позволяет работать с огромным количеством объектов: от твердых образцов до живых клеток, которые должны находиться в жидких растворах. И даже в этом случае мы все равно можем их изучать и контролировать изменения морфологии, структуры поверхности с очень хорошим разрешением, которое достигает единиц нанометров.

Мы изучаем в основном процессы белковолипидных взаимодействий, которые происходят в клетках, в том числе при различных патологиях, в процессах вирусного инфицирования, а также при онкологических заболеваниях. Эта же методика позволяет тестировать эффективность медицинских препаратов, чтобы понять фундаментальные механизмы их действия: с какими молекулами связываются, как и на какие процессы влияют. Исходя из полученной информации, делаются выводы об использовании тех или иных препаратов в клинической практике для борьбы с различными заболеваниями. То, что мы сканируем в физиологических условиях, в жидких растворах, позволяет системе сохранять естественную подвижность. Все белки, которые есть в организме, рецепторы, каналы и т. д. , должны свободно двигаться. При изучении на

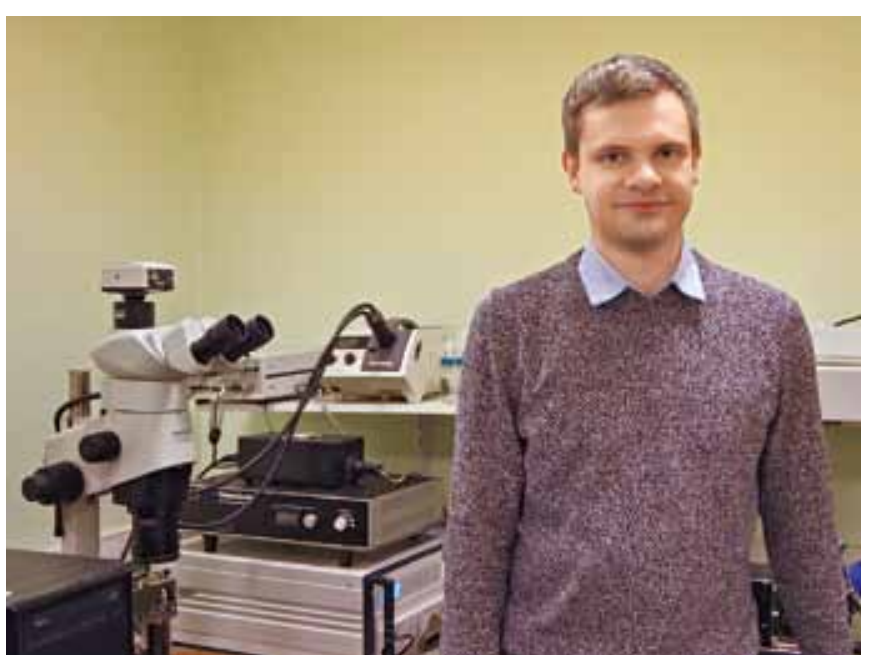

Олег Вячеславович Батищев

исследуемых образцах моделей строения оболочки клетки очень важно сохранить свободу движения. Этот метод позволяет не замораживать определенные состояния, а наблюдать их в динамике и контролировать факторы, влияющие на различные процессы в живых системах.

Поскольку оборудование нашей лаборатории входит в ЦКП, наряду с собственными исследованиями мы также проводим измерения, которые заказывают сотрудники других подразделений. Приведу в качестве примера полимерные образцы с включениями наночастиц: мы определяли их форму и размеры. Другое задание заключалось в исследовании структуры поверхности кварцевого окна после его полировки. Оценка результата важна для отработки технологии очистки. Еще одна работа - изучение свойств полимерных композитных материалов с металлическими порошками в качестве дисперсных наполнителей.

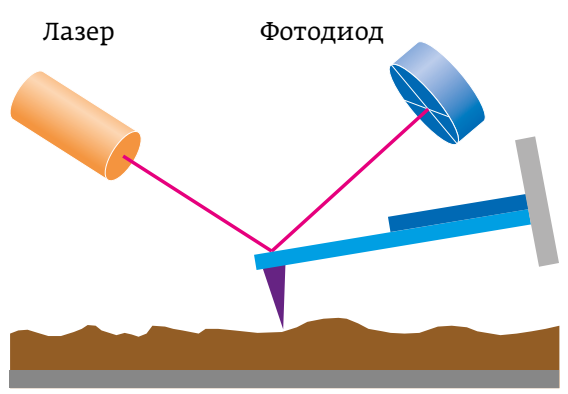

Фотодиод

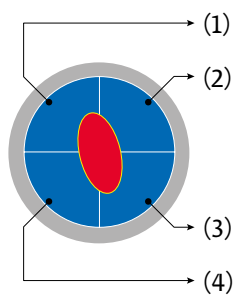

Схема работы атомного сииового микроскопа 


\section{Лаборатория хроматографии и масс-спектрометрии}

\section{Рассказывает директор института, заведующий лабораторией, доктор химических наук Алексей Константинович Буряк}

В нашей лаборатории несколько очень интересных и ценных приборов. Первый - тандемный газовый хромато-масс-спектрометр с тройным квадруполем GCMS-TQ8040 (SHIMADZU, Япония), скорость сканирования 20000 a.е. м. / с без потери чувствительности, скорость регистрации до $800 \mathrm{MRM-переходов}$ в секунду, отношение сигнал / шум составляет более 8000 : 1 (ЕI, 100 фг OFN, m/ z $272 \rightarrow 222$ ).

Второй - масс-спектрометр с индуктивно связанной плазмой Agilent 7500с (США) с квадрупольным масс-анализатором - предназначен для измерения в лабораторных условиях массовой концентрации и изотопного отношения химических элементов в растворах, определения следовых количеств элементов в сверхчистых материалах, используемых, например, в полупроводниковой промышленности (деионизированной воде, органических растворителях и т.п.). Скорость газового потока через колонку - 1,0-2,0 мл / мин; интервал температур 0-350 ${ }^{\circ} \mathrm{C}$; максимальный внутренний диаметр колонки 0,25-0,53 см; чувствительность до $10^{-14}$ г.

Третий - MALDI TOF-спектрометр ultrafleXtreme (Bruker, Германия) - эффективен для протеомики, молекулярной диагностики и анализа белков. Основные характеристики: разрешающая способность - до 40000 , частота импульсов - 1 кГц, самоочищающийся источник ионизации, фокусное расстояние лазера 10 мкм, точность определения масс 1 ppm. Управление прибором и автоматический интерактивный анализ данных происходит с помощью программного обеспечения Compass. Доступны дополнительные пакеты программ для количественного анализа белков, интерпретации МАЛДИ-спектров полимеров, управления проектами в протеомике и т.д.

Сотрудники лаборатории занимаются анализом биологически активных веществ и неорганических материалов. В сферу наших интересов входит изучение коррозионных процессов, которые происходят под действием агрессивных реагентов на поверхности металлических конструкций, в первую очередь, топливных баков. Опубликован ряд работ по методам и средствам защиты от коррозии, в том числе с помощью летучих ингибиторов; создана технология мониторинга коррозионного состояния подземных сооружений; предложены материалы и покрытия, в том числе жаростойкие,

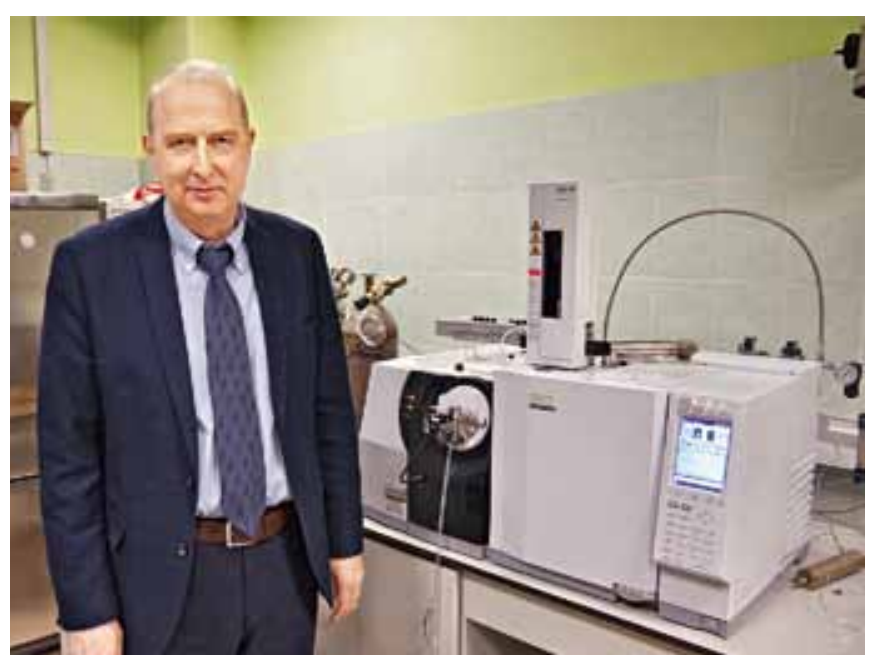

Алексей Константинович Буряк

Тандемный газовый хромато-масс-спектрометр

с тройным квадруполем GCMS-TQ8040

износостойкие, защитные и др. Разрабатываются современные физико-химические методики анализа примесей в компонентах ракетных топлив.

Второе важное направление работы связано с решением экологических проблем. Задача - создание и отработка методик обнаружения и количественного определения токсичных реагентов на поверхности материалов или в грунте. “Жесткие” методы пробоподготовки для работы с биологическими объектами не подходят, поэтому мы используем для

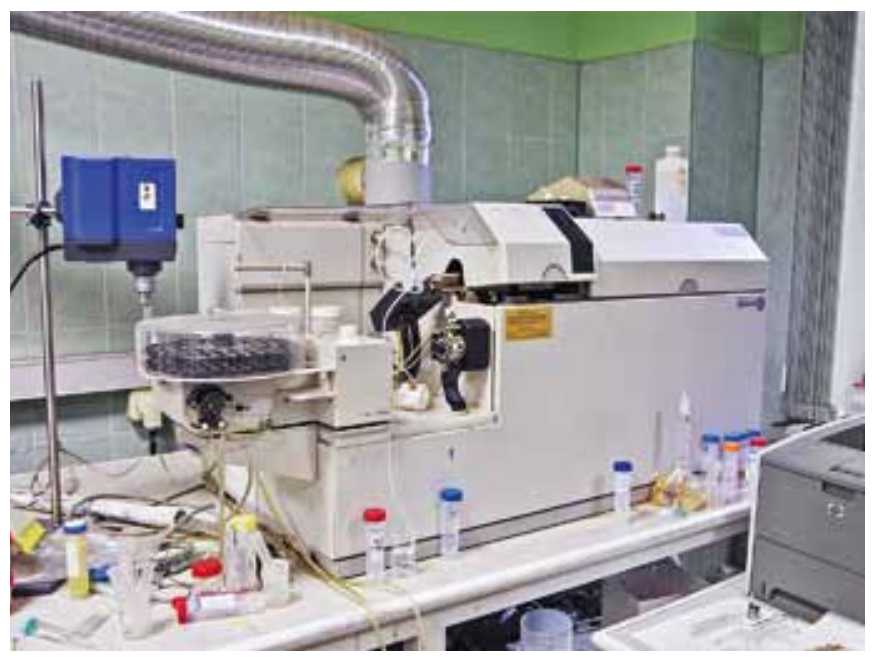

Масс-спектрометр с индуктивно связанной плазмой Agilent 7500c (США) 
поиска промежуточных продуктов мягкое лазерное излучение.

Конечно, этими двумя областями наши интересы не ограничиваются. Всегда будут актуальными фундаментальные исследования, направленные на определение молекулярного веса и выяснение структуры как вновь синтезируемых веществ, так и давно известных сложных соединений.

Хочу отметить роль ЦКП в достаточно благополучной ситуации с приборами в нашей и любой другой лаборатории института. ЦКП - это наше спасение, только благодаря центру у нас есть исправно работающие приборы. В советское время все дорогие приборы приобретались не для конкретной лаборатории, а в центры коллективного пользования. И та лаборатория, которая работала с прибором, часть времени выделяла на обслуживание всего института. В период перестройки система была разрушена, но и сегодня отдельная лаборатория не может поддерживать дорогой прибор. Поэтому мы вернулись практически к прежней схеме приобретения, распределения и работы высокотехнологичного оборудования. К сожалению, наша приборостроительная отрасль практически уничтожена. А немногие приборы отечественного производства очень дороги, потому что многие комплектующие закупаются за рубежом. Да и запчасти стоят дороже, чем изделие в сборе. Даже самая большая лаборатория не может себя содержать, а институт аккумулирует некоторые средства.

Нам нравится работать в структуре ЦКП еще и потому, что со своими задачами к нам обращаются разные специалисты. Это расширяет области применения приборов и сферу нашей деятельности. Так, например, очень интересная работа была связана с определением структуры молекул лекарственных средств с целью подтверждения оригинальности происхождения препарата и т.д. Все-таки мы отдаем предпочтение научным исследованиям, а не отработке методик рутинных анализов.

\section{Лаборатория физики и химии коллоидных систем}

\section{Рассказывает научный сотрудник Андрей Владимирович Шабатин}

Одним из основных приборов нашей лаборатории является сканирующий растровый электронный микроскоп Quanta FEG 650 фирмы FEI. Сканирующая электронная микроскопия - метод универсальный, главное, чтобы поверхность была электропроводящей. Высокое разрешение (до 1 нм) позволяет исследовать практически самые малые объекты в трех режимах: высокий вакуум, низкий вакуум или режим естественной среды. Спектр изучаемых нанообъектов очень широкий:

- металлы и сплавы, окисление/коррозия, трещины, сварные швы, шлифы, магнитные и сверхпроводящие материалы;

- керамики, композитные материалы, пластмассы;

- пленки / покрытия;

- петрографические шлифы, минералы;

- мягкие материалы: полимеры, фармацевтические препараты, фильтры, гели, ткани, растительные объекты;

- частицы, пористые материалы, волокна.

В лаборатории физики и химии коллоидных систем мы работаем с различными материалами, изучаем минералогические образцы, порошки. Например, ультрадисперсный порошок лекарственного препарата после лиофильной сушки.

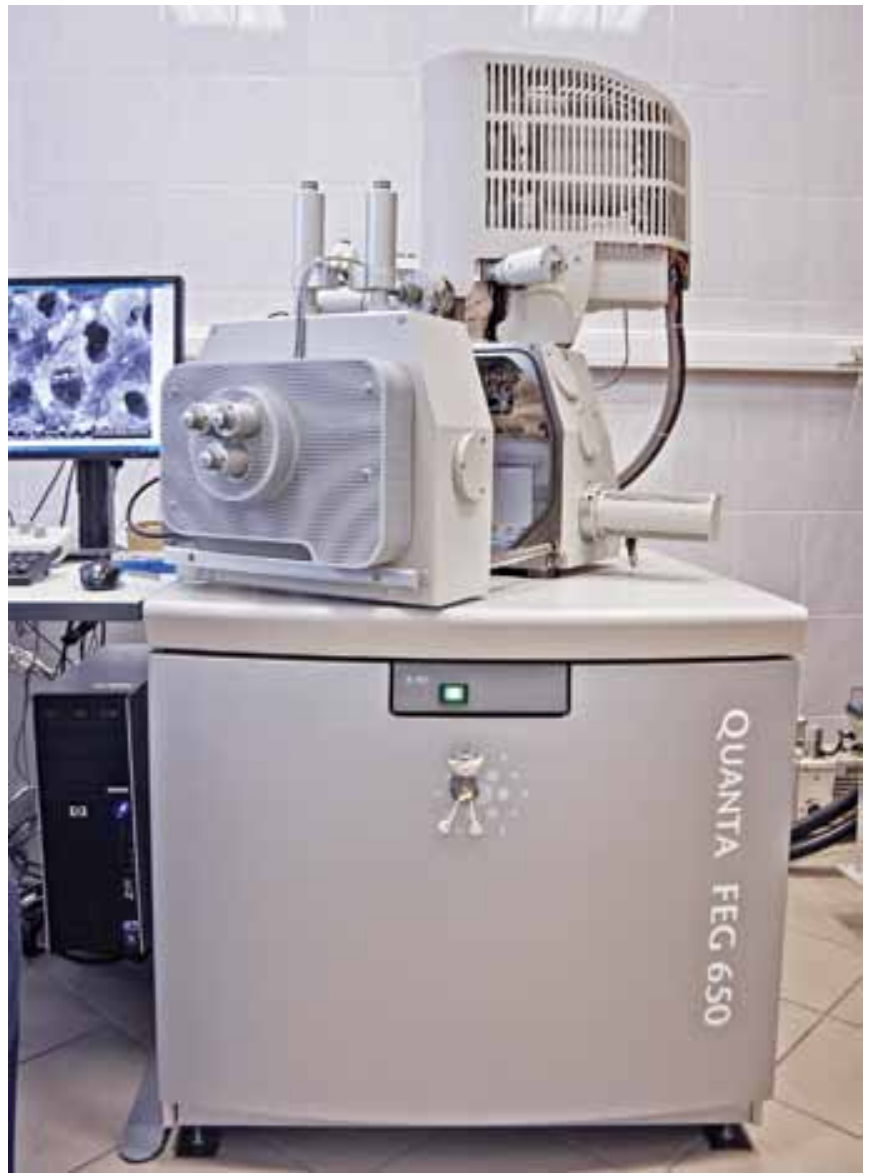

Растровый электронный микроскоп Quanta FEG 650 (FEI) 


\section{НОВЫЕ МОДЕЛИ ОБОРУДОВАНИЯ}

\section{INVENIO X}

\section{ИССЛЕДОВАТЕЛЬСКИЙ ИК-ФУРЬЕ СПЕКТРОМЕТР}

С ВЫСОКОЙ СТЕПЕНЬЮ АВТОМАТИЗАЦИИ /BRUKER, ГЕРМАНИЯ/

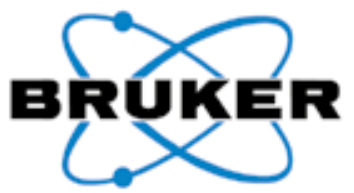

- Широкий спектральный диапазон от $28000 \mathrm{~cm}^{-1}$ до $15 \mathrm{~cm}^{-1}$.

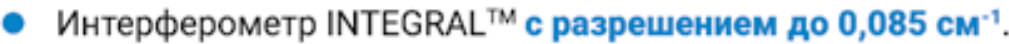

- Уникальная технология Bruker FM, позволяющая регистрировать спектры MIR и FIR за одно измерение.

- Автоматический 3-x позиционный сменщик лучеделителей.

- Технология MultiTect ${ }^{\mathrm{TM}}$, которая позволяет установить до 5-ти детекторов с автоматической сменой.

- Отделение DigiTect ${ }^{\mathrm{TM}}$ для ручной установки детектора.

- Второе встроенное кюветное отделение Transit ${ }^{\mathrm{TM}}$ с собственным детектором.

- Огромное количество приставок для кюветного отделения и внешних модулей для расширения функционала.

- Встроенный компьютер с сенсорным экраном.

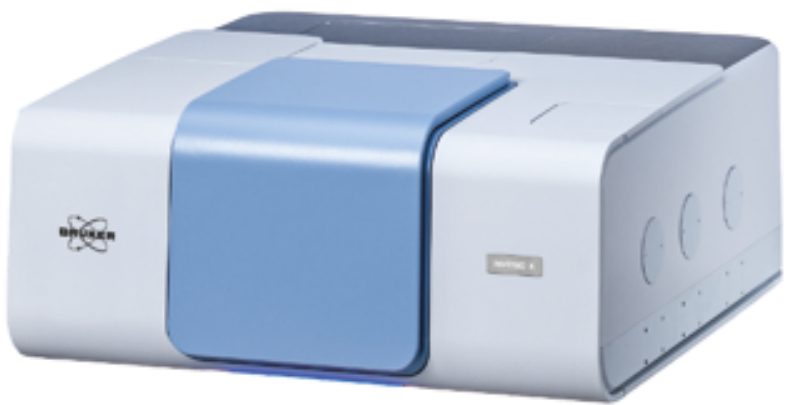

\section{HELIOS HYDRA}

МУЛЬТИФУНКЦИОНАЛЬНАЯ ДВУЛУЧЕВАЯ АНАЛИТИЧЕСКАЯ СИСТЕМА СВЕРХВЫСОКОГО РАЗРЕШЕНИЯ ДЛЯ РЕШЕНИЯ ЗАДАЧ МАТЕРИАЛОВЕДЕНИЯ И БИОЛОГИИ / THERMO SCIENTIFIC, США /

Плазменный ФИП

с четырьмя типами ионов

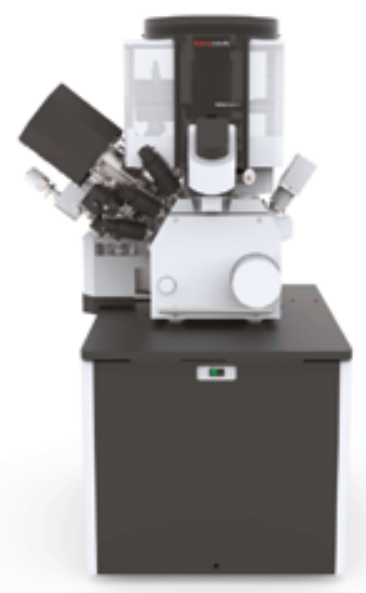

- Анализ широкого спектра материалов благодаря использованию четырёх видов ионов: $\mathrm{Xe+,} \mathrm{Ar}+, \mathrm{Ot}, \mathrm{N}+$.

- Быстрое (до 10 минут), полностью автоматизированное переключение между типами ионного пучка.

- Высококачественная подповерхностная и трехмерная характеризация образцов большого объёма.

- Высокая производительность и качество статистически значимых характеристик.

- Максимальный уровень автоматизации рабочих процессов.

- Подготовка ПЭМ-образцов высочайшего качества независимо от состава и структуры материала.

- Электронная колонна Elstar с монохроматором UC+: разрешение 0,6 нм при 15 кВ, 0,7 нм при 1 кВ.

- Высокопрецизионный 150 мм пьезо-столик для образцов.

\section{Мелитэк}

www.melytec.ru
Mockва

info@melytec.ru +7 (495) 781-07-85

Киев

infoua@melytec.ru +38 (044) 454-05-90
Санкт-Петербург infospb@melytec.ru +7 (812) 380-84-85

Таллин

info@melytec.ee

+372 (5) 620-32-81
Екатеринбург infoural@melytec.ru +7 (343) 287-12-85

Усть-Каменогорск infokz@melytec.ru +7 (7232) 41-34-18 
Еще один пример - исследование в различных режимах резины, обработанной излучением лазера. Полученные снимки позволяют увидеть возникшие поры, исследовать их изнутри, изучать нанометровые включения, проводить корреляцию с изменением различных свойств: упругость, электропроводность, стойкость к износу, излому и т.д.

В нашей практике есть работа по изучению качества лакокрасочных покрытий при использовании разных технологий подготовки и нанесения лака.

Объект особого интереса - соединения серебра. Например, недавно изучали смеси эпоксидной смолы с нитратом серебра, которое при высушивании раствора превращалось в наносеребро. Цель проведенной работы - получение электропроводящей эпоксидной смолы. В воде частицы серебра формируют осадки (эффект кофейного пятна), которые в зависимости от условий испарения организуются различным образом - собираются в диск или в кольцо. Такой вид частиц используется в струйной печати, археологии, медицине, в том числе в различных гибких электропроводящих материалах. Если упорядочить образование осадка, то можно получать различные структуры. Дисперсия наночастиц серебра или капиллярная самосборка - одно из направлений нашей работы.

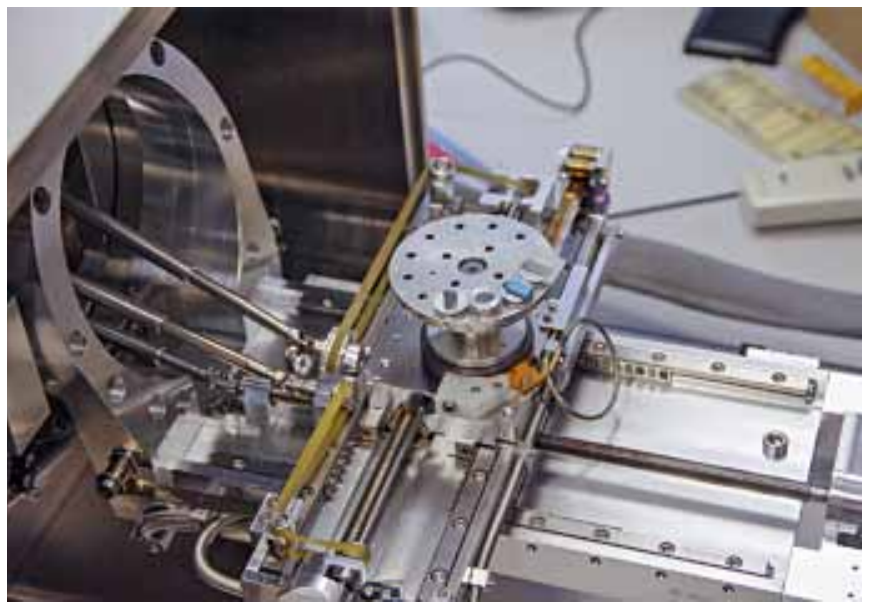

Держатель образиа

Еще одна тематика исследований - биомедицинская - связана с синтезом наночастиц серебра заданного размера в водных растворах хитозанов. Известные способы получения дисперсных растворов приводят к образованию слишком мелких наночастиц, которые не подходят для решения некоторых медицинских задач. Мы отработали методику синтеза частиц нужного размера для конкретных приложений и с помощью коллег из других лабораторий охарактеризовали полученную систему.

\section{Лаборатория физикохимии коллоидных систем}

\section{Рассказывает и. о. заведующего лабораторией, старший научный сотрудник, кандидат химических наук Иван Николаевич Сенчихин}

В нашей лаборатории проводятся фундаментальные работы, связанные с синтезом и стабилизацией наноразмерных коллоидных систем, созданием новых полимерных композиционных материалов, исследованием поверхностных явлений с участием различных соединений, процессов самоорганизации и т. д. Мы ведем как теоретические, так и экспериментальные исследования.

Теоретический подход применяем при построении неравновесной термодинамики и кинетической теории поверхностных явлений, а также в развитии теории фильтрации. В частности, в последнее время предложены математические модели, описывающие процесс тонкой очистки газов от субмикронных и наноразмерных аэрозольных частиц волокнистыми фильтрами. Полученные результаты найдут применение при

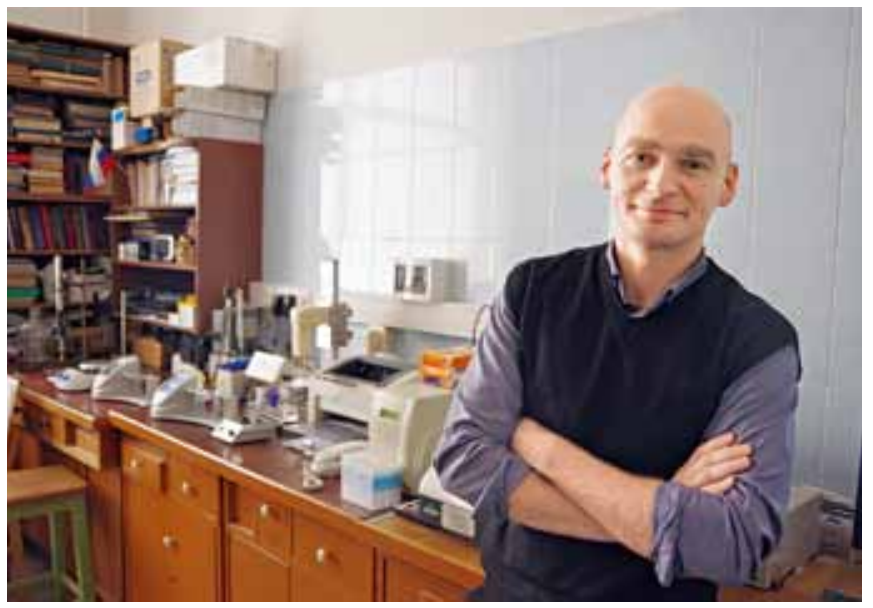

Иван Николаевич Сенчихин

решении практических задач фильтрации газов и жидкостей, мембранного разделения с помощью половолоконных модулей, в катализе, позволят 


\section{$\oplus$ SHIMADZU}

\section{Excellence in Science}

(B)
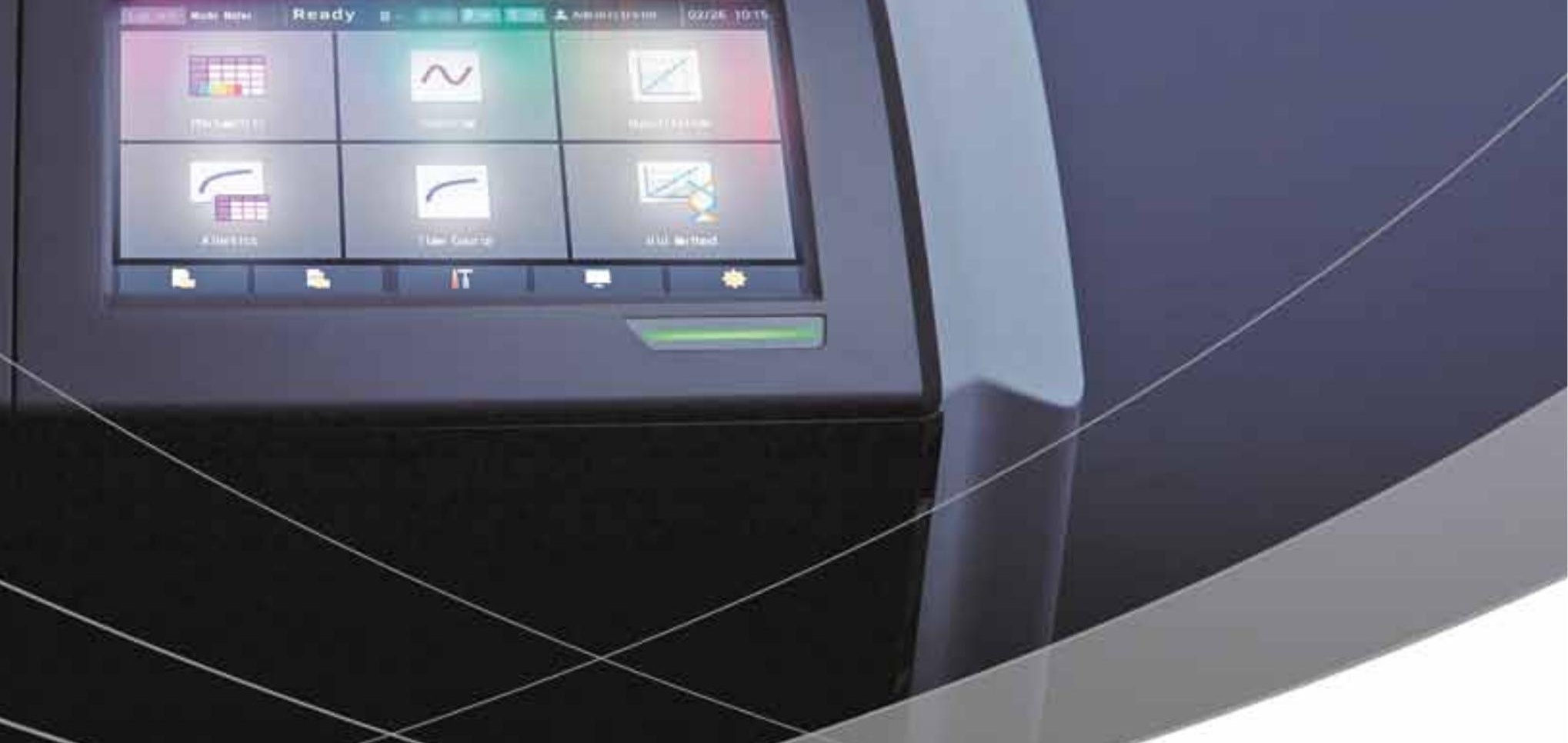

Новинки 2020:

спектрофотометры «UV-i Selection»

- Работают под управлением программного обеспечения LabSolutions UV-Vis, которое обеспечивает комплексное управление данными и безопасность

- Moгут оснащаться автосамплерами ASX-280 и ASX-560

- Cпектрофотометр UV-1900і - возможность подкпючения сканера штрих-кода

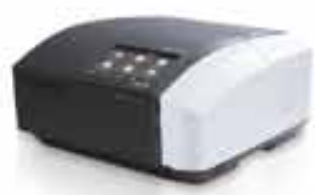

UV-1900i

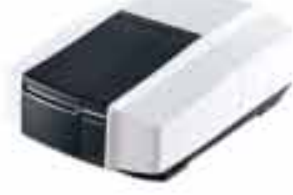

UV-2600i/2700i

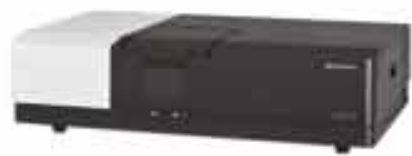

UV-3600i Plus

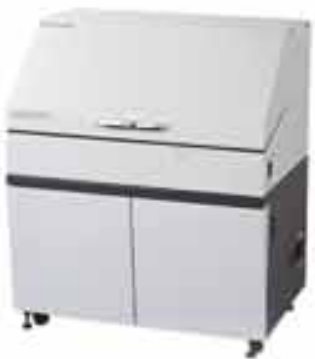

SolidSpec ${ }^{\mathrm{TM}}-3700 \mathrm{i}$

тел.: (495) 989-13-17 www.shimadzu.ru 
создать новые технологии для получения материалов с заранее подобранными свойствами и характеристиками.

Экспериментальные исследования проводим в основном на имеющемся в лаборатории оборудовании различными методами. Например, термоанализа, который реализован в очень интересном приборе под названием - термогравиметрический анализатор (ТГА) Q500 (TA Instruments, США), проще говоря - термовесы. Можно узнать, как меняется масса образца при нагревании в воздушной или инертной атмосфере, получить данные о кинетике протекающих при этом процессов, определить термостабильность системы. А соединив выхлоп печи ТГА с газовой ячейкой ИК-фурье спектрометра Nicolet 6700 (Thermo Fisher), легко провести спектральные исследования продуктов разложения.

Еще один прибор - дифференциальный сканирующий калориметр (ДСК) Q100 (TA Instruments, США). В нем одновременно нагреваются (или охлаждаются) два образца: тот, теплофизические свойства которого мы изучаем, и эталонный (reference), который близок по свойствам к образцу, и в то же время с ним в исследуемом диапазоне температур не происходит никаких изменений. В процессе сканирования регистрируется разница тепловых потоков, проходящих через образцы, в результате получается кривая. Из нее, например, можно определить энтальпию и температуру начала фазового перехода первого рода, получить такую важную характеристику аморфных систем, как температура стеклования, и др. Объекты исследования самые разнообразные: от различных полимеров до липосомальных систем, которые успешно используются как носители лекарств, поэтому задача их изучения очень актуальна.

Круг изучаемых вопросов достаточно широк. Среди них создание и исследование новых полимерных нанокомпозитов с биоцидными свойствами.

Есть у нас "комбайн": совмещенный ТГА-ДСКанализатор Q600 (TA Instruments, США), позволяющий одновременно регистрировать и изменение массы образца, и тепловой поток, отличия в температурном диапазоне и чувствительности по некоторым параметрам.

Для исследования полимеров и композитов активно используется термический механический анализ (термический механический анализатор TMA Q400 EM, динамический механический анализатор ДМА Q800, TA Instruments): по данным об отклике исследуемого образца на приложение

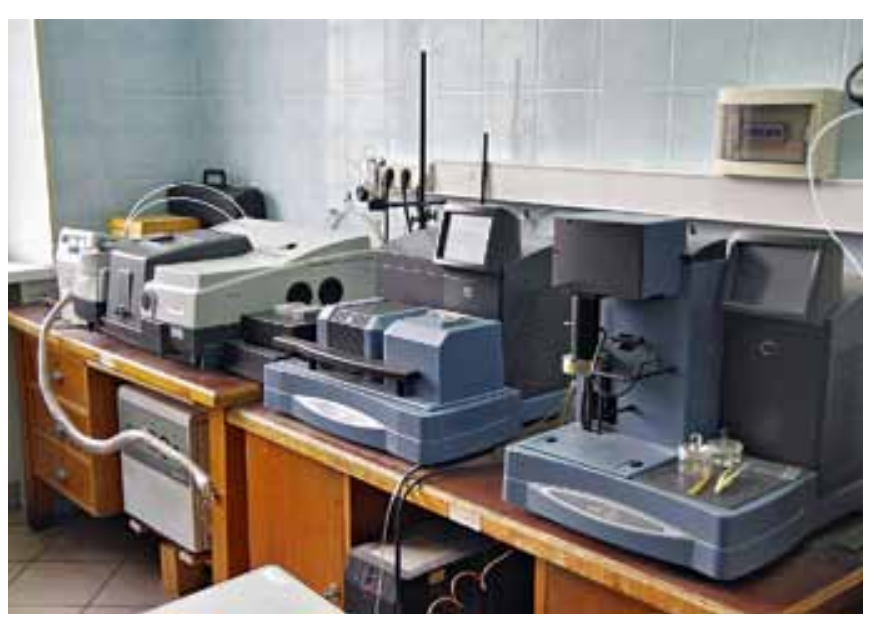

Комплекс приборов для термоанализа

внешнего воздействия (изгиб, сжатие, растяжение, сдвиг) при нагревании мы получаем информацию о температурной зависимости модуля упругости, определяем температурные области релаксационных переходов и др. Все пять приборов термоанализа соединены по сети и управляются с компьютера.

Расскажу еще об одном приборе - анализаторе размеров частиц Zetasizer Nano ZS (Malvern, Великобритания), в основе работы которого лежит метод динамического светорассеяния (ДРС). Прибор позволяет определить размеры наночастиц в дисперсиях, а также электрокинетический потенциал, характеризующий устойчивость коллоидной системы. Одно из направлений нашей работы разработка методов синтеза наночастиц, в частности благородных металлов, в различных средах. Наночастицы по природе своей неустойчивы, поэтому получение стабильных (агрегативно устойчивых) дисперсных систем является актуальной и важной задачей.

Таким образом, комплекс приборов нашей лаборатории дает возможность решать различные научные задачи, изучать структуру и динамику разнообразных систем.

Отмечу, что приборы входят в парк оборудования ЦКП, поэтому мы работаем не только по собственным тематикам, но и решаем различные задачи по заказу научных коллективов нашего института и других исследовательских центров. Кроме того, в рамках деятельности научно-образовательного комплекса (HOK) института студенты-дипломники изучают у нас основы современных методов исследования.

Желаем успехов на ниве отечественной и мировой науки! 


\section{Осмометры криоскопические Advanced Instruments Inc. (LLC)}

Осмометры криоскопические Advanced Instruments Inc. (LLC)

Полностью автоматический режим всех стадий анализа

Объём пробы - 20 мкл-250 мкл

Диапазон измерений от 0 до $4000 \mathrm{mOsm} / \mathrm{kg} \mathrm{H} 2 \mathrm{O}$

Модели для обработки одной или нескольких проб одновременно

Результат 1-3 мин.

Нет необходимости ежедневной калибровки

Подходит для образцов с любой вязкостью

Свидетельство УТ СИ (средства измерения) № 72846-18

Модельный ряд

Osmo1, OsmoPro, 3320, 3250, Fiske 210, A20, OsmoTech

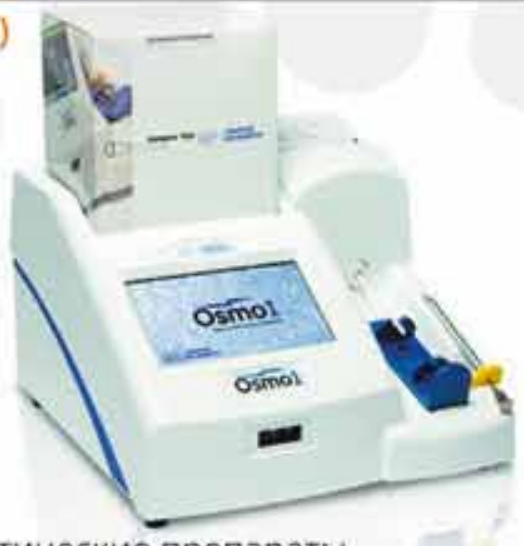

- Мониторинг состава и порядок внесения компонентов в фармацевтические препараты

- Контроль назальных, офтальмологических средств и растворов для ингаляций

- Проверка химической чистоты растворов

- Культуры клеток, культуры тканей

- Парентеральное питание

- Растворы электролитов

- Анализ воды

- Спортивное питание

- Кардиоплегические растворы

- Контроль препаратов для химиотерапии

- Контроль состава питательных сред

- ГОСТ Р 55578-2013 Продукты пищевые специализированные. Метод определения осмоляльности

- Контроль осмоляльности адаптированного детского питания

Принцип работы осмометров компании Advanced Instruments

В осмометрах Advanced Instruments использован метод криоскопии. Выполнение всех стадий анализа с помощью осмометра осуществляется полностью в автоматическом режиме и позволяет получать результаты с высокой точностью и воспроизводимостью. Пользователь только устанавливает емкость с пробой в держатель и запускает процесс измерения с помощью кнопки «старть. Прибор выводит результаты в единицах измерения осмоляльности mOsm $/ \mathrm{kg}$ (МиллиОсмоль/кr).

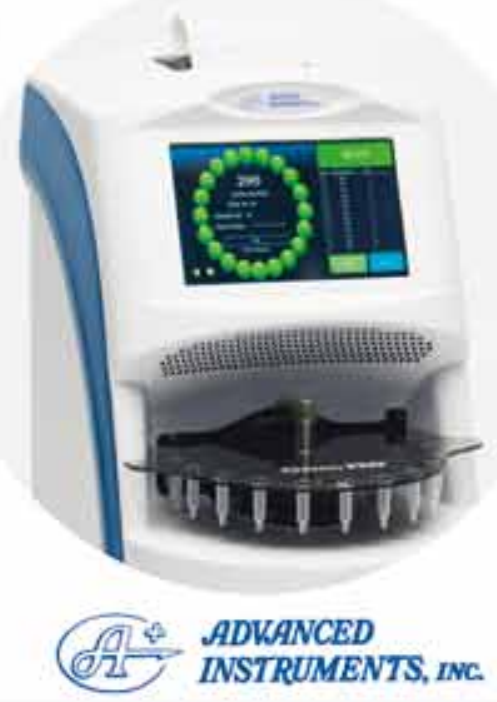

\section{Как выбрать осмометр:}

\begin{tabular}{|c|c|c|c|c|c|}
\hline Осмометр & Osmotech & Osmo1 & Osmopro & A2O & Advanced 3250 \\
\hline $\begin{array}{c}\text { Количество проб } \\
\text { на борту }\end{array}$ & Одноканальный & Одноканальный & $\begin{array}{l}\text { Многоканальный, } \\
20 \text { проб }\end{array}$ & $\begin{array}{c}\text { Многоканальный, } 20 \\
\text { про6 }\end{array}$ & Одноканальный \\
\hline Размер пробы & $20 \mathrm{MKn}$ & 20 мKл & 20 MKл & $100 \mathrm{MkJ}$ & 250 MKn \\
\hline Внесение образца & $\begin{array}{l}\text { Одношаговое } \\
\text { прямое }\end{array}$ & $\begin{array}{l}\text { Одношаговое } \\
\text { прямое }\end{array}$ & $\begin{array}{c}\text { Емкость } \\
\text { Aлst образча }\end{array}$ & $\begin{array}{l}\text { Автоматизированное } \\
\text { из емкости } \\
\text { дия образца }\end{array}$ & $\begin{array}{c}\text { Емкость } \\
\text { для образца }\end{array}$ \\
\hline $\begin{array}{c}\text { Аиапазон } \\
\text { измерений }\end{array}$ & $\begin{array}{c}0-2000 \mathrm{MOCM} / \mathrm{kr} \\
\mathrm{H} 2 \mathrm{O}\end{array}$ & $\begin{array}{c}0.2000 \mathrm{MOcm} / \mathrm{kr} \\
\mathrm{H} 2 \mathrm{O}\end{array}$ & $\begin{array}{c}0-2000 \mathrm{MOcm} / \mathrm{kr} \\
\mathrm{H} 2 \mathrm{O}\end{array}$ & $0-4000 \mathrm{MOCM} / \mathrm{kr} \mathrm{H} 2 \mathrm{O}$ & $\begin{array}{c}0.4000 \mathrm{MOCM} / \mathrm{Kr} \\
\mathrm{H} 2 \mathrm{O}\end{array}$ \\
\hline Время измерения & 90 секунд & 90 секунд & 120 секунд & 180 секунд & 120 секунд \\
\hline $\begin{array}{c}\text { Метод контроля } \\
\text { температуры }\end{array}$ & Сухое охлаждение & Сухое охлаждение & Сухое охлаждение & Сухое охлаждение & $\begin{array}{l}\text { Oxлаждающцая } \\
\text { ванночка } \\
\text { с жидкостью }\end{array}$ \\
\hline Принтер & Опционально & Встроенный & Встроенный & Встроенный & Встроенный \\
\hline & & \multicolumn{4}{|c|}{ 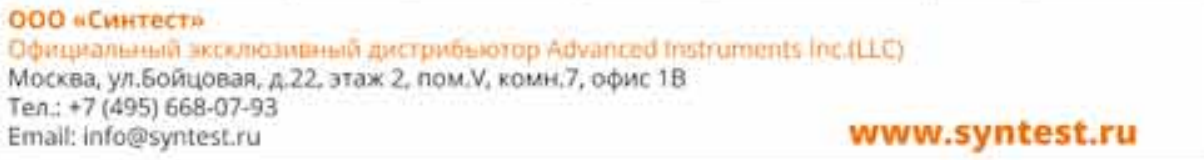 } \\
\hline
\end{tabular}

